\title{
Functional Food Market Development in Serbia: Motivations and Barriers ${ }^{4}$
}

\author{
Article history \\ Received: 17. May 2013 \\ Sent for revision: 17. May 2013 \\ Received in revised form: 20. October 2013 \\ Accepted: 23. October 2013 \\ Available online: 06. November 2013
}

Abstract: The aim of this paper is to present main findings obtained from the empirical analysis of the functional food market in Serbia. The analysis is based on the in-depth interviews with relevant processors and retailers present on the market. The following set of topics are considered: (1) motivations (driving forces) and barriers to offer products with nutrition and health (N\&H) claim and (2) perception of consumer demand toward N\&H claimed products. Differences between Serbia and other Western Balkan Countries (WBC) are explored by using nonparametric tests based on the independent samples. Results support overall conclusion that this market segment in Serbia is underdeveloped and rather producer than consumer driven compared to more developed WBC markets.

Keywords: Product; Motivation; Market; Food market; Demand; Consumers;

\section{Razvoj tržišta funkcionalne hrane u Srbiji: motivacije i prepreke}

Apstrakt: Cilj ovog rada je da predstavi najrelevantnije nalaze dobijene na osnovu empirijske analize tržišta funkcionalne hrane u Srbiji. Analiza je zasnovana na dubinskm intervjuima sa predstavnicima industrije i maloprodaje prisutnim na tržištu. Analiza se odnosi na sledeći set tema: (1) motivacije $i$ prepreke za ponudu proizvoda sa nutritivnim i zdravstvenim izjavama (NiZ), i (2)

\footnotetext{
1 University of Belgrade, Faculty of Economics, zaklina@ekof.bg.ac.rs

2 University of Belgrade, Faculty of Economics, radmilam@ekof.bg.ac.rs

${ }^{3}$ University of Belgrade, Faculty of Economics, galja@ekof.bg.ac.rs

${ }^{4}$ The research is supported by the FP7 FOCUS-Balkans, Grant Agreement no 212579 and the Project No. III-46001, Ministry of Education and Science, Republic of Serbia.
} 
Stojanović Ž. Et al.: Functional Food Market Development in Serbia: Motivations and...

percepcija potrošačke tražnje prema proizvodima sa NiZ izjavama. Razlike između Srbije $i$ drugih zemalja Zapadnog Balkana (ZB) su analizirane korišćenjem neparametarskih statističkih testova zasnovanih na nezavisnim uzorcima. Nalazi podržavaju opšti zaključak da je ovaj segment tržišta u Srbiji, pri poređenju sa razvijenijim tržištima $Z B$, nerazvijen $i$ više vođen akcijama proizvođača, a ne potrošača.

Ključne reči: Proizvod, motivacija, tržište, tržište hrane, potražnja , potrošači.

\section{Introduction}

During the 1990-s, government policies, both in developed and developing countries, put more focus on health promotion and preventive measures against illnesses. Thus health has become a life-long project of keeping well and fit, including self-control and continuous work towards better body status (Burrows et al., 1995; Petersen and Lupton, 1996; Strauss and Thomas, 1998). As a result, food consumers have become generally well aware of the importance of balance, variability and moderation as the cornerstones in eating healthfully (IEFS, 1996a). Public discussion about the future of eating behaviour and the potential adverse effects of health claim products have become an important topic in scientific literature (Lawrence and Germov, 1999; Roe et al., 1999; Nestle, 2007; Garde, 2008). On the other hand, a new food category termed 'functional foods' (foods marketed as improving health and well-being beyond the health effects of conventional foods) gained a substantial market presence in the 1990s (Diplock et al., 1999) and started to develop rapidly in market volume during the last decade.

The market of products with N\&H claims was initiated during mid 1990`s - first in dairy and than in other sectors of food industry. Contrary to the above mentioned trends observed in more developed countries, the market development of such products in Serbia was not followed by significant scientific interest. Generally, little attention has been paid to the market analysis of N\&H claims products, both from consumer's and producer's point of view. The analysis of regulatory framework, medical and technological aspects are present at elementary level. Vast majority of articles about products with $\mathrm{N} \& \mathrm{H}$ claims (functional food) have been published in medical journals by authors that have medical affiliation or medical background (Šobajić, 2002, Miletić et al., 2008). There are several theoretical articles emphasizing health benefits coming from consumption of functional food or analyzing legal environment and regulations regarding this food type (Stanković and Djordjević, 2002). A few papers analyze possible contribution of marketing and technology to the offer of food with N\&H claims (Dimitrijević-Branković et al., 2002; Ristić, 2003). In general, there has been a lack of data about consumers' knowledge and their 
attitudes towards functional food, with the first studies starting to appear only recently (Ognjanov and Stojanović, 2012).

Within the fields of existing $\mathrm{N} \& \mathrm{H}$ claims, products development and commercialization (supply side of the food market), the scientific literature focuses on conceptualization of the innovation process, identification of market opportunities and regulatory/business environment (Van Kleef et al., 2002; Stewart-Knox and Mitchell, 2003; Gray et al., 2003; Mark-Herbert, 2004). Moreover, innovative process oriented research has been developed in a specific case-study context and largely with a focus on Europe (Broring et al., 2006; Peng et al. 2006). However, the studies published in international journals, mostly present the findings obtained in developed European countries, while there is still a lack of data in the developed markets such are those of the Western Balkans.

This paper presents the most relevant findings on products with nutrition and health $(\mathrm{N} \& \mathrm{H})$ claims in Serbia that have been obtained from in-depth interviews conducted with experts - producers and retailers. ${ }^{5}$ All provided results refer to Serbia in comparison with other Western Balkan countries (WBC - Slovenia, Croatia, Bosnia and Herzegovina, Montenegro and FYR Macedonia). Since the same research methodology has been applied in each WBC, the results we present for Serbia are highly comparable to those obtained in other five countries of the region. The main purpose of this paper is twofold: (1) to present the main findings about $\mathrm{N} \& \mathrm{H}$ claimed products market in Serbia based on indepth interviews with processors and retailers, and (2) to test the differences between Serbia and other WBC with respect to processors' and retailers' motivations (i.e. the driving forces) and barriers to produce/sell $\mathrm{N} \& \mathrm{H}$ claimed products as well as their perception of consumer demand. The findings support general theoretical knowledge obtained from various studies previously conducted in more developed economies.

\section{Research Questions and Methodology}

In our study we focused on the following sets of research questions while trying to better understand both sides (supply and demand) of the market: (1) What are the basic motives and restraints that have lead to the development/underdevelopment of the N\&H product market in Serbia? Are there any differences between food system stakeholders regarding this issue? Are there any differences among WBC? (2) Could healthy diet be considered

5 The first version of this paper is presented at the 1st Joint EAAE and AAEA International Seminar (Nutritional \& Health Claimed Products Market Development in Serbia: Exploration of Findings Obtained from in-Depth Interviews). 
as the primary motive for consumption? Could consumer knowledge and price of products be considered as the major barriers for heavier consumption of $\mathrm{N} \& \mathrm{H}$ products? Are there any other important barriers? Are there any differences regarding this issue among WBC?

The research methodology applied in the analysis of functional food consumption in WBC is based on a multi-technique (a number of both qualitative and quantitative research techniques was used) and multistakeholder approach (a number of different stakeholders were interviewed). Thus, mentioned research techniques are used to collect as much as possible information in order to contribute to better understanding of the characteristics of $\mathrm{N} \& \mathrm{H}$ claimed products market. Different families of $\mathrm{N} \& \mathrm{H}$ products have been covered by this study: milk and nectars enriched with vitamins and minerals, dietetic jam, light margarine and yoghurt with probiotics.

Any kind of market research provides better information if it is based on previously determined supply structure. Therefore, for the purposes of our study we used linear and specialized store check as the most reliable method for obtaining the data revealing the existing supply structure. Additional benefit was reflected in the detailed structure of manufacturers offering studied categories of product in the market. Hence, the store check served us as a basis for sampling since it has provided the list of producers to be invited to participate in interviewing. The store check was conducted in mayor retail chains including: international retail chain, regionally present retail chain, the key retail chain present only at the domestic market and key retail chain of the so-called healthy food (specialized shops).

The producers included in our sample were interviewed using the strict methodology of in-depth interviews as a well accepted qualitative research technique. The instrument used was a specially designed questionnaire comprising of mostly open-ended questions emphasizing the qualitative, indepth aspects of an issue. Close-ended questions were also used only as a part of already established open-ended issues and only after the spontaneous response of the interviewees. These included different forms - dichotomous (yes or no) question, multiple choice question, rank order scaling and rating scales questions. Probing and follow-up questions were used whenever it was possible and required.

Interviewees were asked about overall attitude toward consumers demand, main criteria and restraints for consumer's choice, perceived consumers' characteristics and each stakeholder cross-perception. Additionally, processors and retailers were asked to provide insights about markets - the current state, trends and perspectives. In total, 29 out of 45 producers were interviewed (respondent rate $71 \%$ ). Additionally, seven EU exporters of studied categories of products regionally present in WBC are interviewed. Finally, 26 key retailers present in all WBC are also covered by the analysis. Looking at the number of 
Stojanović Ž. Et al.: Functional Food Market Development in Serbia: Motivations and...

observations, the research is based on the total of 120 products (an interview covers two categories of products surveyed by a questionnaire; the number of observed products in relation to the interviews done is 62 for processors and 58 for retailers). The list of processors and retailers included into the analysis enables high rate of research reliability. The whole analysis in the paper is based on the structure of respondents in Serbia presented in Table 1.

Table 1. Structure of in-depth interviews in Serbia

\begin{tabular}{|c|l|c|}
\hline \multirow{1}{*}{ Criteria } & \multicolumn{1}{|c|}{ Structure } & No of interviews \\
\hline \multirow{4}{*}{$\begin{array}{c}\text { Category of } \\
\text { products with } \\
\text { H\&N claim }\end{array}$} & Jam for persons suffering from diabetes & 4 \\
\cline { 2 - 3 } & Yogurt with probiotics & 5 \\
\cline { 2 - 3 } & "Light margarine" with reduced fat content & 6 \\
\cline { 2 - 3 } & Juice enriched with vitamins and minerals & 7 \\
\cline { 2 - 3 } & Other products & 2 \\
\hline \multirow{3}{*}{ Stakeholder } & Processor & 10 \\
\cline { 2 - 3 } & Retailer & 5 \\
\hline
\end{tabular}

Source: Focus-Balkans WP6 research database, www.focus-balkans.org

The purpose of the analysis in the following part is to test differences between Serbia and other WBC with respect to perception of processors and retailers on motivations, barriers and consumer demand of $\mathrm{N} \& \mathrm{H}$ products. In order to find out whether significant differences in those attitudes exist between the mentioned countries, we choose nonparametric testing procedure based on two independent samples (Daniel, 2000). Mann-Whitney (MW) test is provided as it examines whether two groups are drawn from the same population on the basis of the rank of each group and the sum of ranks. The test is equivalent to the Wilcoxon rank sum test and the Kruskal-Wallis test for two samples. It could be used for the medians comparison of the two groups but only when a rather restrictive assumption is fulfilled: population distributions may be different only in location, not in shape. When this assumption is not satisfied, MW test cannot be used for testing difference between medians of the two populations. The reason for this is the fact that MW statistics could have a $p$-value equals to 0 indicating statistically significant differences between median of the two groups even in case they are identical. 


\section{Findings and Elaboration}

\subsection{The main findings from in-depth interviews in Serbia}

In order to find out the most important driving forces for N\&H products supply, the interviewees are asked for spontaneous answers on their motivation either to produce or sell these products on the market. After the spontaneous response mentioned motives were ranked from 1-5 according to their importance ( 1 is the most and 5 the least important). In Serbia processors find that improvement of company's image is the most important motive for the development of products with $\mathrm{N} \& \mathrm{H}$ claims. Opposite to that, the least important motives are following the EU trends and improving company's market position. Accordingly, introducing such products is perceived to be leading to the improvement of a company's image rather than shifting a company's market position (e.g. of a follower to overcome leaders). Most of the interviewees said that their margins for products with $\mathrm{N \& H}$ claims are higher than their margins for regular products. However, the share of products with $\mathrm{N} \& \mathrm{H}$ claims is very low in their total sale. Therefore, it is understandable that the profit is not ranked higher on this motivation scale than improvement of company's image. Some companies mentioned that they launched products with N\&H claims in order to be socially responsible, to broaden their assortment and to educate consumers in Serbia.

Similar to motivation, barriers for N\&H products supply are at first spontaneously mentioned by the companies' representatives. After that, they are asked to mark mentioned barriers on the scale from 1 to 5 , where 1 means not important at all. Regarding the barriers, the respondents seem to perceive all problems in product development to be almost equally treated and not so important (average mark is from 1.70 to 2.50). Problems in R\&D are the least important among all. Scientific problems (relations with research centres in the country, scientific programs publicly supported in the area of food and biotechnology, etc.) are recognized as the most problematic, especially for the dairy sector. Most of the interviewed firms reported no significant financial problems during products development (half of the respondents marked it 1 on 5 point scale). However, many of them seem to have a problem with insufficient knowledge of consumers' needs (average mark is 2.30). The processors also identified some other barriers, such as: decrease in purchase power due to the world economic crisis, long period of waiting to obtain necessary licenses, short shelf life of some ingredients and high market competitiveness (particularly in dairy sector). Processors think that consumers are generally uninformed about benefits of products with $\mathrm{N} \& \mathrm{H}$ claims and that they need better publicly supported education. They are also ready to educate their consumers by specific promotional activities. 
Similar to producers, the interviewed retailers spontaneously point out the image as the main driving force to sell these products. Answering the consumer's demand and improving the market position are in the second and third place, respectively. It is obvious that retailers generally see these products as an ideal tool for improvement of perceived market position. It is a way to create and keep position with consumers. Median rank of profit motivation is 4, indicating possible increase of the profit motivation in the future. The main barriers for N\&H claim products are consumer related. Consumer's awareness, low demand and eating habits are pointed out as the main problems for retailers concerning the studied categories. Consumers are not aware of these categories and they mostly do not include them in their diets. Availability of products, logistic difficulties, price and competition are not seen as important problems.

Majority of processors think that price and taste are the most relevant criteria when consumers decide whether to buy products, while labels are the least important. It means that consumers should be more educated about labels in the future. The processors think that consumers do not consider safety and health aspects when they do their shopping. Overall conclusion is that consumers are very price sensitive. Additionally, most of the retailers put price criterion in the first place for consumer choice of food. Consumers purchase power is low and they often avoid buying products which are more expensive than the average ones. Hence, the main reason why consumers do not buy products with N\&H claims more in Serbia are seen as a part of the broader economic restraint. On the other hand, processors do not think that they are responsible for the low demand for this kind of products. However, retailers and processors point out that Serbian government does not pay enough attention to development of national policy for nutrition. They think that consumers get all information on this topic from the media, and that producers must put their own efforts in education of consumers on this matter in the future. It is also interesting that nutritive knowledge restraints are perceived to be slightly more important than habit restraints, meaning that diet habits could be overcome with education.

\subsection{Motives and barriers to offer products with N\&H claims}

Regarding processors' motivation to develop products with N\&H claims, test results show that differences between Serbia and other WBC are not statistically significant (Table 2). 
Stojanović Ž. Et al.: Functional Food Market Development in Serbia: Motivations and...

Table 2. Differences in motives to offer N\&H products between Serbia and other $W B C$ - results of Man-Whitney test

\begin{tabular}{|lll|ll|}
\hline Man-Whitney test & \multicolumn{2}{c|}{ Processors } & \multicolumn{2}{c|}{ Retailers } \\
\hline Motivations & Test statistics & $p$-value & Test statistics & $p$-value \\
\hline Profit & -0.142 & 0.887 & -1.376 & 0.169 \\
Image & -0.716 & 0.474 & -1.267 & 0.205 \\
Consumer demand & -1.166 & 0.244 & -0.737 & 0.461 \\
EU trend & -1.453 & 0.146 & $-2.962^{* * *}$ & 0.003 \\
Market position & -1.191 & 0.234 & -1.319 & 0.187 \\
\hline *Significant at 10\% significance level. ${ }^{* *}$ Significant at $5 \%$ significance level. ${ }^{* * *}$ Significant at $1 \%$ \\
significance level.
\end{tabular}

Source: Authors' calculation.

As far as retailers' motivations to sell $\mathrm{N} \& \mathrm{H}$ products are concerned, similar conclusions can be derived. According to the test results, differences between Serbia and other WBC appear to be insignificant, with one exception. The only significant difference between retailers is related to their perception on the importance of following the trend as in European countries as a motive in making decision to sell $\mathrm{N} \& \mathrm{H}$ products. This motive seems to be more important in other WBC (the median and mode rank equals 3) then in Serbia (both median rank and mode are 5). Here, rank 1 means the most important motive, whereas the rank 6 implies the least important motive.

Concerning the main problems to develop N\&H products, significant differences between the processors' opinion in Serbia and in other WBC were not found (Table 3). It seems that processors from all WBC perceive the problems in the same way. For instance, both processors from Serbia and other WBC state that they have no problems such as financial, scientific, regulation, $R \& D$ problem (mode and median marks are 1 or 2 , except info-problem where these marks equal 3). With respect to retailers' problems in meeting consumer's demand of $\mathrm{N} \& \mathrm{H}$ products, it could be said that significant differences between Serbia and other WBC appear only in one problem, that is in difficulties of relationship with foreign companies (value of $\mathrm{MW}$ test statistics $=-2.054$ is significant at 5\% level; Table 3). 
Stojanović Ž. Et al.: Functional Food Market Development in Serbia: Motivations and...

Table 3. Differences in barriers to offer N\&H products between Serbia and other WBC - results of Man-Whitney test

\begin{tabular}{|c|c|c|c|c|}
\hline \multirow{2}{*}{$\begin{array}{l}\text { Man-Whitney test } \\
\text { Motivations }\end{array}$} & \multicolumn{2}{|c|}{ Processors } & \multicolumn{2}{|c|}{ Retailers } \\
\hline & $\begin{array}{l}\text { Test } \\
\text { statistics }\end{array}$ & $p$-value & $\begin{array}{l}\text { Test } \\
\text { statistics }\end{array}$ & $p$-value \\
\hline Financial problem & -0.320 & 0.749 & & \\
\hline $\begin{array}{l}\text { Scientific assistance } \\
\text { problem }\end{array}$ & -1.062 & 0.288 & & \\
\hline Regulation & -0.049 & 0.961 & & \\
\hline R\&D problem & -0.272 & 0.786 & & \\
\hline Info problem & -0.904 & 0.366 & & \\
\hline Availability & & & -1.586 & 0.113 \\
\hline Foreign competitiveness & & & $-2.054^{* *}$ & 0.040 \\
\hline Price & & & -0.684 & 0.494 \\
\hline Logistic difficulty & & & -1.470 & 0.141 \\
\hline Low demand & & & -0.891 & 0.373 \\
\hline Consumer awareness & & & -0.888 & 0.374 \\
\hline Habit problem & & & -0.032 & 0.975 \\
\hline Competition & & & -0.241 & 0.809 \\
\hline
\end{tabular}

Source: Authors' calculation

While retailers operating on the Serbian market, report insignificant difficulties of relationship with foreign companies (all interviewed retailers mark this problem as not important at all or not important), retailers present at the rest of WB market (mostly from underdeveloped $\mathrm{N} \& \mathrm{H}$ claimed products market in Macedonia, B\&H and Montenegro) reported slightly higher marks for this problem ( 7 out of 19 retailers have positive perception of this problem existence).

\subsection{The processors' and retailers' perception of consumer demand and behavior for N\&H products}

Speaking about processors' opinion on the consumer perception and behaviour for its $\mathrm{N \& H}$ products, the WBC could be observed as a rather 
Stojanović Ž. Et al.: Functional Food Market Development in Serbia: Motivations and...

homogenous region. Test results show insignificant differences in processors' perceptions of the importance of any criteria of consumer's choice of products for the company's family of products (Table 4).

Table 4. Differences in the perception of N\&H claimed products consumer demand between Serbia and other WBC - results of Man-Whitney test

\begin{tabular}{|c|c|c|c|c|}
\hline \multirow[t]{2}{*}{ Man-Whitney test } & \multicolumn{2}{|c|}{ Processors } & \multicolumn{2}{|c|}{ Retailers } \\
\hline & Test statistics & $p$-value & Test statistics & $p$-value \\
\hline Demand high & -1.538 & 0.124 & -1.355 & 0.175 \\
\hline \multicolumn{5}{|l|}{ Food choice criteria } \\
\hline Price & -0.738 & 0.461 & $-1.757^{*}$ & 0.079 \\
\hline Taste & -0.334 & 0.739 & -1.594 & 0.111 \\
\hline Safety & -0.287 & 0.774 & -0.862 & 0.389 \\
\hline Freshness & -1.010 & 0.312 & -0.444 & 0.657 \\
\hline Health dimens. & -0.739 & 0.460 & -0.392 & 0.695 \\
\hline Label & -0.430 & 0.667 & $-2.086^{\star *}$ & 0.037 \\
\hline \multicolumn{5}{|l|}{ Barriers } \\
\hline Price & $-2.316^{\star *}$ & 0.021 & -0.760 & 0.447 \\
\hline Econ. difficulty & $-2.507^{\star \star}$ & 0.012 & -0.739 & 0.460 \\
\hline Nutrition knowledge & -0.501 & 0.617 & -0.187 & 0.852 \\
\hline Availability & -1.537 & 0.124 & $-1.767^{*}$ & 0.077 \\
\hline Habits & -1.190 & 0.234 & -0.276 & 0.782 \\
\hline National policy & -0.685 & 0.493 & -0.156 & 0.876 \\
\hline \multicolumn{5}{|l|}{ Factors of change } \\
\hline Nutrition knowledge & -0.504 & 0.615 & -0.972 & 0.331 \\
\hline Health & -0.395 & 0.693 & -1.600 & 0.110 \\
\hline Public policy & $-1.651^{*}$ & 0.099 & $-2.280^{\star *}$ & 0.023 \\
\hline Purchase power & -0.477 & 0.634 & -0.776 & 0.437 \\
\hline Lifestyle & -1.353 & 0.176 & -0.728 & 0.467 \\
\hline Fashion & $-1.933^{\star *}$ & 0.050 & -1.539 & 0.124 \\
\hline Consumer changes & $-1.985^{\star \star}$ & 0.047 & -0.607 & 0.544 \\
\hline
\end{tabular}

Source: Authors' calculation.

The processors from the whole region ranked the importance of observed criteria in similar way. For instance, most of the processors from Serbia and those from other WBC answered that the price criteria, following by taste criteria are the most important (mode rank for price is 1 and for taste is 2 both in Serbia and other WBC; median ranks for price and taste are 2 in Serbia, while in other WBC are 3 and 2, respectively). Conversely, labels and indication of origin are ranked as the least important criteria (mode and median rank is 6 in both cases). 
Regarding retailers' perception, there are differences in perceiving the importance of price criteria as well as labels and indication of origin (values of test statistics are significant at $10 \%$ and $5 \%$, respectively). Retailers in Serbia perceive price criteria as more important than taste, freshness and health related criteria (median rank of the later is 3 ), while health dimension of diet is seen as the most important criteria for consumer choice of food in other WBC (particularly in Slovenia and Croatia). As far as the importance of other criteria is concerned, retailers in Serbia have no statistically different statements in comparison to those in other WBC.

With respect to the main restrictions for consumers to buy products with N\&H claims, significant differences between processors' perception refer to two restrictions: price and economic difficulties (both $\mathrm{MW}$ test statistics are significant at 5\%; see Table 4). Processors in Serbia consider N\&H claimed products less available to the consumers who are exposed to more significant economic difficulties (both median and mode is 5 compared to 4 in other WBC). Moreover, there is some indication of differences in perception of availability constraint between retailers, as that difference is significant at $10 \%$. In case of other WBC, eating habits are seen as the most important restriction for consumers to buy products with N\&H claims.

Within the analysis of perspectives about future consumption of products with $\mathbf{H} \& \mathbf{N}$ claims, one of the main questions refers to the factors of change in future food consumption. Observing by countries, it seems that processors in Serbia have similar statements as processors in other WBC with respect to the following factors of change: consumer nutritional knowledge, health dimension of food, change in purchasing power and lifestyle. Some indications of differences are related to public policy factor (at $10 \%$ significance level) while statistically significant difference (at $5 \%$ significance level) is found in case of fashion as a factor of change in future food consumption. Fashion is perceived as more important in Serbia than in other WBC. Opening of Serbian borders will bring more competitiveness and educated persons who will be more aware of $\mathrm{N} \& \mathrm{H}$ products additional health benefits than they are today. It is also important to note that nutritional knowledge, as a factor in consumption, is highly marked both in Serbia and other WBC (median mark is 5).

Concerning retailers' perception, it seems that those from Serbia and other WBC have different statements only regarding public policy as a factor of change in future consumption of $\mathrm{N} \& \mathrm{H}$ products (value of $\mathrm{MW}$ test statistics is significant at 5\%). The retailers in Serbia do not expect significant change of the public policy as they mark this factor importance lower than retailers in other WBC. This also implies conclusion that retailers do not expect any significant changes in consumers demand due to the inconsistent public support both in the terms of incentives to offer and promote these products as well as to provide better education for the consumers. 
Stojanović Ž. Et al.: Functional Food Market Development in Serbia: Motivations and...

\section{Conclusion and Implications}

Most of $\mathrm{N} \& \mathrm{H}$ claimed products in Serbia were introduced by domestic companies from the year 2000. It is obviously the new market segment addressed to the innovators and early adopters. The most important findings obtained from in-depth interviews about motivation, barriers and perception of consumer demand for N\&H claimed products in Serbia can be summarized as follows:

- Processors find that the improvement of company's image is the most important motive for the development of products with N\&H claim.

- The main barriers for the market development are consumer related. Most of the interviewees think that price and taste are the most relevant criteria when consumers decide whether to buy food products.

- The differences in motivation and barriers for N\&H claimed products market development between Serbia and other WBC appear to be insignificant, with a few exceptions.

- The market segment is rather producer than consumer driven.

The labels used on food are not so important for consumer choice in Serbia. It might be marked as an essential obstacle for the further $\mathrm{N} \& \mathrm{H}$ claims product market development our country. Therefore, further promotion of $\mathrm{N \& H}$ claims products should primarily be based on communicating the idea of its value added related to health with no trade-off regarding its taste. The pricing strategy should be built upon the awareness of very high consumer price sensitivity but also in line with the specific expectations or readiness to pay for additional health benefits offered by those products. Against such a backdrop, it is obvious that a primary step for better acceptance of $\mathrm{N} \& \mathrm{H}$ claims products by the local consumers as well as for the overall market development in future is strongly related to raising consumer awareness of the concept of functional food. The actions in this direction should be undertaken both by the marketers but also public policy makers. In particular, public policy in the future should be certainly governed toward consumer education on nutritional and health labeling. The former includes not only providing general information on availability of nutritional and health labeling, but also education how to use it and what information to search for when deciding which food products to buy and consume.

Regarding motivations and barriers, the analysis shows that the differences between Serbia and other WBC appear to be insignificant, with a few exceptions. As far as retailers opinion is concerned, following the trend as in European countries as motive and difficulties of relationship with foreign companies as a problem seem to be more important in other WBC then in Serbia. Speaking about the consumer perception and behaviour, there are 
differences between Serbian retailers and those from other WBC in perceiving the importance of price criteria as well as labels and indication of origin. However, processors in Serbia consider N\&H claimed products less available and more expensive than in other WBC. Within the analysis of perspectives about future consumption of products with $\mathrm{H} \& \mathrm{~N}$ claims, some indications of differences are related to the public policy factor while statistically significant difference is found in case of fashion as factor of change in future food consumption.

Finally, since the health motivation is not emphasized as an important motive for food consumption in Serbia, the market segment is rather producer than consumer driven. Contrary to this finding, consumers are treated as the main driving force in more developed functional food markets in the region (Slovenia and Croatia). However, it is also important to underline that perceptions of healthy food are exposed to turbulent environment in Serbia, such as changes in market structure, changes in regulation, internationalization and increase of competition. The development of the functional food market remains less predictable mainly due to changes in consumers' purchasing power, increased awareness on the importance of food and nutritional knowledge, as well as to inconsistent public health policies completely neglecting the possible role that the food system stakeholders might have in promotion of healthier diet within the region.

\section{References}

Bröring, S., Martin, C.L., \& Leker, J. (2006). The front end of innovation in an era of industry convergence: evidence from nutraceuticals and functional foods. R\&D Management, 36(5), 487-498. doi:10.1111/j.1467-9310.2006.00449.x

Burrows, R., Nettleton, S. and Bunton, R. (1995). Sociology and health promotion. Health, risk and consumption under late modernism. In: The Sociology of Health Promotion (ed. by R. Bunton, S. Nettleton \& R.Burrows), pp. 1-9, Routledge, London.

Daniel, W. W. (2000). Applied Nonparametric Statistics (2nd ed.). Boston: Duxbury Press.

Dimitrijević-Branković, S.I., Baras, J.K., \& Bojović, J. (2002). Značaj i mogućnosti proizvodnje funkcionalne hrane. Hemijska industrija, 56(3), 113-122. Retrieved from doi:10.2298/HEMIND0203113D http://scindeks.ceon.rs/article.aspx?artid=0354-75

Diplock, A.T., Agget, P.J., Ashwell, M., Bornet, F., Fern, E.B. and Roberfroid, M.B. (1999). Scientific concepts of functional foods in Europe: consensus document. British Journal of Nutrition, 81, S1-S27.

Garde, A. (2008). Food Advertising and Obesity Prevention: What Role for the European Union. Journal of Consumer Policy, 31(1), 25-44. doi:10.1007/s10603007-9061-2 
Stojanović Ž. Et al.: Functional Food Market Development in Serbia: Motivations and...

Gray, J., Armstrong, G., \& Farley, H. (2003). Opportunities and constraints in the functional food market. Nutrition \& Food Science, 33(5), 213-218. doi:10.1108/00346650310499730

IEFS (1996). A Pan-European Survey of Consumer Attitudes to Food, Nutrition and Health. Report Number Three. Definitions of Healthy Eating, Barriers to Healthy Eating and Benefits of Healthy Eating. Institute of European Food Studies, Dublin.

Lawrence, M. and Germov, J. (1999). Future food: the politics of functional foods and health claims. In: A Sociology of Food and Nutrition. The Social Appetite (ed. by J. Germov and L. Williams), pp. 54-76, Oxford.

Mark-Herbert, C. (2004). Innovation of a new product category-Functional foods. Technovation, 24 (9), pp. 713-719.

Miletić, I., Sobajić, S. and Djordjević, B. (2008). Funkcionalna hrana - uloga u unapređenju zdravlja. Journal of Medical Biochemistry, 27 (3), str. 367-370.

Nestle, M. (2007). Food Politics: How the Food Industry Influences Nutrition and Health (2nd ed.). University of California Press, Berkeley and Los Angeles.

Peng, Y., West, G.E., \& Wang, C. (2006). Consumer Attitudes and Acceptance of CLA-Enriched Dairy Products. Canadian Journal of Agricultural Economics, 54(4), 663-684. doi:10.1111/j.1744-7976.2006.00072.x

Petersen, A. and Lupton, D. (1996). The New Public Health. Health and Self in the Age of Risk. SAGE Publications, London.

Ristić G.N. (2003). Funkcionalna hrana - hrana za XXI vek, Mlekarstvo, 2 (14), pp. 428-433.

Roe, B., Levy, A.S. and Derby, B.M. (1999). The Impact of Health Claims on Consumer Search and Product Evaluation Outcomes: Results from FDA Experimental Data. Journal of Public Policy \& Marketing, 18(1), pp. 89-105.

Stanković, I.M. and Djordjević, B.I. (2002). Funkcionalna i nekonvencionalna hrana zakonska regulativa, Hrana i ishrana, 43 (1-2), pp. 60-62.

Ognjanov, G., Stojanović Ž. (2012). Stavovi potrošača na Zapadnom Balkanu prema oznakama na prehrambenim proizvodima, Marketing, 43 (2), pp. 113-121.

Stewart-Knox, B., \& Mitchell, P. (2003). What separates the winners from the losers in new food product development. Trends in Food Science \& Technology, 14(1-2), 58-64. doi:10.1016/S0924-2244(02)00239-X

Strauss, J. and Thomas, D. (1998). Health, Nutrition and Economic Development. Journal of Economic Literature, XXXVI (June 1998), pp. 766-817.

Šobajić, S. (2002). Funkcionalna hrana u prevenciji bolesti i terapiji. Arhiv za farmaciju, 52 (3), pp. 369-375.

Van Kleef, E., van Trijp, H. and Jongen, W. (2002). Consumer-oriented functional food development: How well do functional disciplines reflect the "voice of the consumer"? Trends in Food Science \& Technology, 13 (3), pp. 93-101. 